\title{
Dijital Dünyada Yeni Vatandaşlık Konsepti: Estonya'da E-Vatandaşlık Örneği
}

\author{
DOI: 10.26466/opus.869773
}

*

\author{
Hatice Koc * \\ * Dr., Atatürk Kültür, Dil veTarih Yüksek Kurumu \\ E-Posta: haticemineozkan@gmail.com \\ ORCID:

\section{Öz}

Estonya, e-devlet uygulamaları ve e-hizmetleri açısından gelişmiş bir Avrupa ülkesidir. Bağımsızlığını kazandıktan sonra yeni devlet inşasın teknoloji üzerine kuran Estonya'nın e-devlet sistemi; yasal ve teknolojik altyapl, toplumun teknoloji yanlısı bir kültüre sahip olması gibi nedenlerden dolayı güçlüdür. Estonya, dünyada seçim süreçlerinin tümünü internete taşıyan ilk ülkedir. Bu başarısıyla ulusal bir marka haline gelen Estonya, 2014 yilında tüm dünyaya dijital hizmetlerini kullanma ve Avrupa Birliği networkünü kullanma imkanı sağlayan E-vatandaşlık uygulamasını başlatmışıtı ve bu uygulama dünyada ilk ve şu an için tektir. Bu çalışma, Estonya'da başlatılan ve herhangi bir ülkenin vatandaşının dijital ortamda başka bir ülkenin vatandaşı olmasına imkan veren vatandaşlıkla ilgili yeni bir söylem getiren e-vatandaşlık uygulamasını araştırmaktadır. E-vatandaşlık uygulaması geleneksel vatandaşlik, devlet sınırları, küreselleşme gibi kavramların yeniden sorgulanmasına yol açmıştır ve dönüştürücü etkisiyle bu kavramlar derinden etkileme potansiyeline sahiptir. Ancak uygulama, dijital ortamla fiziksel ortam arasında derin bir bariyere sahiptir başka bir deyişle e-vatandaş sanal ortamda sahip olduğu imkanlara fiziki olarak, ülkeye girmesi de dahil, sahip değildir. Bunun yan sıra fiziki ortamda hukuki olarak herhangi bir yabancıdan farksız olan e-vatandaş, yerine getirmesi gereken yükümlülükler açısından da özellikle kişisel verilerin korunması noktasında pek çok dezavantajlarla karşı karşıyadır. Bu yönüyle eleştirilen e-vatandaşlık konsepti, Estonya tarafindan geliştirilmeye ve diğer ülkelere yayılmaya çalışılmaktadır.

Anahtar Kelimeler: e-devlet, dijitalizasyon, e-vatandaşlık konsepti 


\title{
The New Citizenship Concept In The Digital World: Case Of E-Citizenship In Estonia
}

\begin{abstract}
Estonia is a developed European country in terms of e-government applications and e-services. Egovernment system of Estonia which established its new state construction upon the technological infrastructure after the independence claims to be strong due to the legal and technologic substructure and its society's technology-friendly culture. Estonia is the first country running all processes of elections over internet, a success which makes Estonia a national brand. In 2014, the state commenced E-citizenship which enables the whole world to use its digital services and EU network and this is the first and only practice in the world. This study investigates e-citizenship which enables citizens of any countries to attain citizenship of another country and thus brings about a new discourse on citizenship. E-citizenship project lies behind the re-examination of the concepts like traditional citizenship, state borders, globalization and has a potential to influence them deeply via its transformative power. But, the application has a deep barrier between the digital and physical environments. In other words, e-citizen does not have its digital opportunities in physical settings, even as the entrance to the country. In addition to this, e-citizen does not differ from a foreigner in physical settings legally, and even he is subjected to many disadvantages about his obligations especially in terms of protection of personal data. The concept of e-citizen is tried to be developed by Estonia and spread to other countries despite the above-mentioned critics.
\end{abstract}

Keywords: e-government, digitalisation, the concept of e-citizenship. 


\section{Giriş}

E-Estonya, devletin tüm unsurlarını kapsadığı ve vatandaşların günlük yaşamlarını değiştirdiği için günümüzde dijital devlet yönetimindeki en iddialı e-devlet uygulamalarından biridir. Estonya, devletin verdiği yasama, oylama, eğitim, adalet, sağllk hizmetleri, bankacılık, vergiler, polislik vb. tüm hizmetleri tek bir platforma toplayarak halkın kullanımına açmıştır. 1991 yılında Rus işgalinden bağımsızlı̆̆ını kazandığından beri yeni toplum ve devlet inşasını teknolojik altyapı ile birlikte kuran Estonya, yasal ve teknik altyapıdan başlayarak devlet uygulamalarını teknolojinin üzerine inşa etmiştir. Kurduğu sistemde altyapıya ve güvenliğe önem veren devlet $X$ road ile adem-i merkezi bir e-devlet yapılanmasına gitmiş ve bunu ekimlikle güvence altına almıştır.

Estonya, toplumun e-devlet ve teknoloji kabulü için de geniş bant uygulaması, internetin insan hakkı olarak tanınması, internet erişimini yaygınlaştırılması gibi ayrı projeler geliştirmiştir. Toplumun \%95'i kamu hizmetini edevlet üzerinden almaktadır. Seçimleri internet üzerinden yapmaya başlamiştır.

2014'ten başlayarak Estonya, dünyanın her yerinden insanlara evatandaşlık imkanı sağlayan bir uygulama başlatmıştır. E-vatandaşlık, yabancılara güvenli bir dijital kimlik verilmesini ve Estonya'nın dijital hizmetlerinden faydalanmasına imkan tanıyan bir uygulamadır. Uygulama sayesinde E-vatandaşlar, resmi belgeleri ve sözleşmeleri dijital olarak imzalayabilmekte, imzalanan belgelerin gerçekliğini doğrulayabilmekte, belgeleri güvenli bir şekilde şifreleyebilmekte, Estonya'da çevrimiçi bir şirket kurup yönetebilmekte, e-bankacılık ve uzaktan para transferleri gibi işlemleri yapabilmekte, çevrimiçi ödeme hizmeti sağlayıcılarına erişebilmekte ve vergilerini çevrimiçi beyan edebilmektedir.

E-vatandaşlık yüksek güvenlikli bir kimlik sistemi ve yalın bürokrasi üzerine kurulu bir e-devlet sistemine dayandığı için dünyanın her yerinden e-devlet hizmetinin alınabilmesine imkan sağlamaktadır. İşlem sayıları düşük ve hızı yüksek olduğu için kullanıcılara avantaj sağlamaktadır. Estonya Avrupa Birliği ülkesi olduğu ve e-devlet sisteminin güvenilirliği ile bilindiği için kullanıcılara hem hukuki hem de teknik anlamda kimliği ile ilgili yapttğ işlemlerde Avrupa Birliği güvencesi sağlamaktadır. 
Estonya e-vatandaşlara kendi e-devlet hizmetlerinin yanı sıra Avrupa Birliği networkünü kullanma imkanı sağlamaktadır.

Estonya, her dünya vatandaşına, bir şirketi çevrimiçi olarak etkili ve güvenli bir şekilde kaydettirmeye ve yönetmeye izin veren, devlet tarafından verilmiş bir uluslararası dijital kimlik sunan ilk ülkedir. Bu yönüyle uluslararası ortamda çok fazla ilgi görmüş ve e-vatandaşlık Estonya'nın bir ulus markası haline gelmiştir. 60 bini aşan e-vatandaşların arasında Japonya Başbakan Shinzo gibi isimler mevcuttur. Başvuranların üçte birinden fazlası başvuru nedenini dijital dünya vatandaşı olmak, sınırları aşmak olarak belirtmiştir.

E-vatandaşlığın ulus markası haline gelmesi ulusal markalama perspektifinden eleştirilere maruz kalmıştır. Bu eleştirinin yanı sıra pratikteki uygulama eksiklikleri de e-vatandaşlı̆̆ın eleştirilmesine neden olmuştur. Yeni bir uygulama olması, birden artan ilgi nedeniyle uluslararası ortamın beklentilerinin yüksek olması ve uygulayıcıların kendi sistemini öngörülemeyecek birtakım risklere karşı koruma refleksi ile hukuki ve teknik bir çerçeve geliştirmesi uygulamanın başarısına ve potansiyel katkılarına gölge düşürmektedir.

Bu çalışma, Estonya'da yenilikçi bir yaklaşımla 2014 yılında başlatılan ve herhangi bir ülkenin vatandaşının dijital ortamda başka bir ülkenin vatandaşı olmasına imkan veren vatandaşlıkla ilgili yeni bir söylem getiren evatandaşlık uygulamasını araştırmaktadır. Estonya "e-devlet" projesindeki e-vatandaşlık uygulaması geleneksel vatandaşlık, devlet sınırları, küreselleşme gibi kavramların yeniden sorgulanmasına yol açmıştır ve dönüştürücü etkisiyle bu kavramları derinden etkileme potansiyeline sahiptir. Bu amaçla öncelikle Estonya'daki dijital dönüşüm ana hatları ile resmedilmiş ardından e-vatandaşlık uygulamasının teoride sınırlarını zorladığı kavramlara dair bir tartışma yürütülmeye çalışılmış son olarak e-vatandaşlık uygulamasının bireyler ve ilgili ülkeler açısından faydaları ve olası riskleri tartışılmıştır.

\section{E-Vatandaşlığın Dijital Ve Yasal Ekosistemi: E- Estonya}

E-vatandaşlık, tek başına oluşturulmuş spesifik amacı olan bir proje değildir. Aksine Estonya'daki süregelen e-devlet projesi ve uygulamalarının değişim ve gelişiminin bir uzantısıdır. Bu nedenle e-vatandaşlık kavramını, 
işleyişini ve sonuçlarını tartışmadan önce politik, yasal, kurumsal ve teknik çerçevesini oluşturan e-Estonya projesi ve dijital dönüşümünden bahsetmek gerekir.

Estonya, kamu kurumları ve vatandaşların günlük işlerinin e-çözümleri konusunda iyi uygulama örneklerinden biri olarak bilinmektedir. Estonya, 1990 yılında Sovyetler Birliği'nden bağımsızlığını kazandığından beri dünya ekonomisinde aktif bir rol oynamak ve uluslararası sermaye için cazibe merkezi olmak için önemli adımlar atmıştır. Estonya, Avrupa Birliği, Birleşmiş Milletler, NATO, Avrupa Güvenlik ve İşbirliği Teşkilatı, Ekonomik İşbirliği ve Kalkınma Teşkilatı ve Baltık Denizi Devletleri Konseyi'nin üyesidir. Pek çok uluslararası kuruluş nezdinde uluslararası yatırım ve ticaret için olumlu bir destinasyon olarak değerlendirilmektedir.

Estonya söz konusu güveni kazanabilmek için yönetişimi teknoloji tabanında temellendirmiş ve kurduğu e-yönetişim sistemi ile hizmetlerini özel sektör ve gerçek kişiler dahil olmak üzere kamuya sunma konusunda iddialı bir konuma yükselmiştir. Hizmetler, kamu-özel ortaklığı ile tasarlanmakta ve sürdürülmektedir. Estonya'nın başarısı uluslararası ortamda ilgi çekmiş ve tecrübe paylaşımı ve işbirliği için ülkeler arası ikili uygulamalar yanında Estonya deneyimini yaygınlaştırmak için E-yönetişim akademisini kurmuştur (Nielsen, 2017, s.300).

E-Estonya'nın başlangıcını, Estonya'nın Sovyetler Birliği'nden bağımsızlığını kazandığı 1991 yılına kadar götürmek mümkündür. Bağımsızlığın hemen arkasından demokratik geçiş, ekonomik ve sosyal gelişim gibi konularda planlama yapılırken ana tüm bu sektörlerin ve projelerin arkasında güçlü bir dijital altyapı stratejik hedef olarak belirlenmiştir. Bu nedenle Estonya'nın yaşadığı dijital süreç aslında e-dönüşüm değil yeni devletin dijital üzerine inşa edilmesidir. Estonya, sıfırdan başladığı kamu hizmetlerini zamanın en yeni bilgi teknolojilerine yaptı̆̆ yatırımlarla desteklemiştir. 1990'lar teknolojiye yatırım yılları olarak da adlandırılabilir (Anthes, 2015, s.18). Bu dönemde yatırımların yanında bugünün e-Estonya'sının da temeli olan iki proje başlatıldı: Kimlik kodu sistemi ve e-devlet altyapısı (Kotka, Vargas ve Korjus, 2015, s. 2). 


\section{Isıkukood:e-Kimlik sistemi}

E- vatandaşlığın ve e-Estonya'nın temel yapı taşını isikukood (Estonya Kişisel Kimlik Kodu) oluşturmaktadır. İsikukood 1990 yılında, Estonya'nın Sovyetler Birliği'nden kurtarılmasından önce muhalif hareketlerin yerli Estonya nüfusunu kaydetmesi ve organize etmesi için işgale karşı bir araç olarak tasarlanmıştır. Daha sonra Sovyetler Birliği tarafından açıkça yasaklanan bu uygulama bağımsızlıktan sonra e-kimlik sistemine dönüştürülmüş ve gelinen noktada sistem, fiziksel olarak ülkede ikamet etmeyenlerin de erişebileceği şekilde genişletilmiştir (Kotka, Vargas ve Korjus, 2015, s. 2). E-kimlik projesi ilk olarak 1998 yllında gündeme gelmiş ve 2002'de vatandaşlara verilmiştir (Hartleb, 2020, s.215). İsikukood, vatandaşların ve evatandaşların tüm kamu hizmetlerine, bankacılık işlemlerine ve ticari işlemlere eriştiği temel araç olmuştur. İsikukood e-imzanın fiziksel imza gibi geçerliliğini mümkün kılmaktadır. Sunduğu e kimlik numarası ile birden fazla vatandaşlı̆̆ın getirdiği mükerrer işlemlerin de önüne geçmekte ve edevletin güvenlik duvarları için önemli bir altyapı oluşturmaktadır (Aydın, 2021, s.2).

Kimlik kartı, Estonya vatandaşları için sadece fiziksel olarak değil, aynı zamanda dijital ortamda da temel bir kimlik belgesidir. Kimlik kartı Estonya vatandaşları için zorunlu bir belgedir. Dijital imza kimlik kartına yapıştırılır ve özel bir yazılım yardımı ile belgeyi dijital olarak imzalamak mümkündür. Dijital imza, el yazısı ile aynıdır ve iş, hükümet veya özel ilişkilerde kullanılabilir. Her kart, bir kişisel veri dosyası, bir kimlik doğrulama sertifikası ve bir dijital imza sertifikası içeren bir elektronik işlemci çipine sahiptir. Dijital kimlik doğrulama ve dijital imzalamanın güvenliği, Kamu Anahtar Altyapısı tarafından sağlanır (Parsovs, 2020, s.1785). Estonya devleti, bir açık anahtar altyapı işlemlerini garanti eder. Hükümetin iradesi ve girişimleri, Estonya'daki Sovyet sonrası krizin e-devlet bileşenlerinin yardımıyla çözülmesinde çok önemli bir rol oynadı (Anthes, 2015, s.18).

\section{Kamu Anahtar Altyapısı (KAA)}

Estonya'nın dijital kimlik sistemi için halihazırda bir sistemi olduğu için vatandaşlara e-kimlik projesinin başlangıcında güvenlik ile ilgili bir risk görülmemiştir. Kimlik kartlarında bulunan çip, 2048 bitlik bir genel anahtar kullanmakta ve Estonya sistemini destekleyen herhangi bir elektronik or- 
tamda kimliği doğrulayan şifreleme sistemine sahiptir (Priisalu, ve Ottis, 2017, s.441). E-kimlikler, Kamu Anahtar Altyapısında kimlik doğrulama sistemi ile korunmakta böylece e-devletin varlığ 1 ve işleyişi de garanti altına alınmaktadır.

KAA, güvenli kimlik doğrulama ve dijital imzalama için gerekli altyapıdır. Anahtar, kimlik kartlarının elektronik çipinde tutulan bir genel şifreleme anahtarı ve özel bir şifre çözme anahtarından oluşan karmaşık bir kod olarak tanımlanabilir. Kart iki faktörlü kimlik doğrulama ile çalışır - dijital bir hizmete erişmek ve dijital olarak imzalamak için, e-vatandaşa önceden sağlanan güvenli şifrelerin girilmesi gerekir (Parsovs, 2020, s.1786). Bu iki anahtar setinin bir kısmı çipin kart okuyucu cihazlara açıktır ve KAA aracılığıyla ulaşılabilir kılınmıştır, diğer kısmı ise sadece kullanıcı kendi şifresiyle erişebilmektedir. İkinci kısım birinci kısımla koruma altına alındığı için yeniden özel şifre üretmeyi mümkün kılmamaktadır(Priisalu, ve Ottis, 2017, s.441). E-kimlikler için geliştirilen diğer güvenlik önlemleri ise; kimlik kartı olmadan kimlik doğrulamanın yapılamaması, kişisel şifrenin belli bir sayıda yanlış girilmesi halinde kartın bloke olmasıdır. KAA sayesinde Estonya hem kişisel verileri hem de e-devletin güvenliğini ilk adımdan sağlamış olmaktadır (Kalja, Robal, ve Vallner, 2015, s.625).

KAA altyapısının yanısıra Estonya'da "e-Estonya"yı oluşturan ve yayılmasını sağlayan ve e-vatandaşlık uygulamasını gerçekleştirmeyi kolaylaştıracak pek çok BİT girişimi vardır. E-Estonya'nın başarısının altında yalnızca teknolojik altyapı değil bununla birlikte tasarlanan güçlü bir politik ve hukuki çerçevenin geliştirilmesi yatmaktadır. Farklı nitelikte olsalar da eEstonya'nın gelişim seyri için bu girişimler kronolojik sırayla anlatılacaktır.

\section{"Tiger Leap" programı}

Estonya bilgi toplumunu inşa etmedeki ilk girişimlerden biri, 1996 yılında Estonya hükümeti, Bilgi Teknolojileri altyapısının modernize edilmesi ve tüm Estonyalıların İnternet üzerinden bağlanması amaçlayan, devlet tarafından finanse edilen "Tiger Leap" programıdır. Projenin ilk amacı tüm devlet okullarına öğrencilerin kullanabileceği ve birlikte çalışabileceği kişisel bilgisayar sağlamak olsa da proje başarıya ulaştığı için yaygınlaştırılmış proje bir bütün olarak toplumun 'İnternetleşmesini' ifade etmeye başlamıştır (Mets, 2017, s. 1). Proje sayesinde 1998 yılına kadar tüm okulların odalarında 
internet bağlantısı ve bilgisayar vardı ve 2001 yılında ilk Free-Public Wi-Fi bağlantısı kuruldu.

\section{Yasal ve Politik Düzenlemeler}

E-Estonya'nın kilometre taşı olarak kabul edilecek düzenlemelerden biri dijital veritabanı yasasıdır. 1997'de kabul edilen Dijital Veritabanı Yasası dijital veritabanlarının kurulmasından sürdürülmesine kadar tüm süreçlerin yasal çerçevesini oluşturmaktadır. Ardından, 1998'de "Estonya Bilgi Politikasının İlkeleri" dijital strateji politikasına dönüştürülmüş̧ür (Kotka, Vargas ve Korjus, 2015, s. 2).

2000 yılında internete erişim Estonya İnsan Hakları Enstitüsü tarafından temel bir insan hakkı olarak ilan edilmiş ve çevrimiçi hizmetlerde erişimde eşitliği sağlamak için dezavantajlı grupların internet erişimine dönük çalışmalar başlatılmıştır (Björklund, 2016, s.914). Günümüzde Wi-Fi alanları çok yaygındır, çünkü 2011 itibariyle 2,440 kayıtlı ücretsiz Wi-Fi alanı vardı ve 2013 itibariyle 4G, bölgenin\% 95'ini kapsıyordu. 2016 yılında Estonyalıların\% 91'inin internet ve cep telefonu kullanıcısı olduğu kaydedilmiştir (de Carlos Sola, 2018, s.2).

\section{Altyap Olarak X-road}

2001 yılının sonunda, Estonya e-devletinin güçlü yönünü oluşturan teknolojik altyapının temel unsuru olarak da değerlendirilebilecek "X-Road" kullanılmaya başlanmıştır. X-Road, devletin bilgi sistemleri ile kamusal olmayan bilgi sistemlerinin güvenli ara bağlantılarını sağlayan bir değişim katmanıdır. Kurumlar, organizasyonlar ve vatandaşlar birbirleriyle iletişim kurmak için bu dijital ara katmanı kullanmaktadır. Tüm e-hizmetler bu katmandan verilir ve alınır. Bu katmanın güvenliği de e-vatandaş numarası ile sağlanmaktadır (Kalvet, 2012, s.142). X-Road, ulusal dijital altyapının omurgasını oluşturdu ve toplumun farklı alanlarında kamu ve özel e-hizmetlerin daha da geliştirilmesi için temel oldu.

X-Road, ülkenin hem kamu hem de özel sektördeki çeşitli e-hizmet veritabanlarının bağlantı kurmasına ve uyum içinde çalışmasına olanak tanıyan çok önemli bir ortamdır. X-Road, olası saldırıları önlemek için Guardtime tarafından geliştirilen K.S.I. adlı bir blok zincirine dayanmaktadır. Estonya veri tabanlarında veri akışı merkezden çevreye değil çevreden merkeze 
doğrudur, veritabanının tek sahibi yoktur, her kurum, şirket, organizasyon ya da kişi kendisi için uygun olan veri tabanını kullanır ve yeni hizmetler hazır olduklarında birer birer eklenebilir. Estonya devleti kağıtsız ve dijital bir devlet işleyişini X-road sayesinde gerçekleştirmektedir (Lember, Rainer, ve Tõnurist, 2018, s.222). X-Road, yerel ana bilgisayarlardan gelen bilgileri ve tüm veritabanlarını birbirine bağlayarak, maksimum verimlilikle birlikte çalışmalarını sağlamaktadır. Giden veriler dijital imzalar ve şifreleme ile korunur ve gelen veriler doğrulanır.

2003 yılında Estonya www.eesti.ee portalında tüm e-hizmetleri toplayıp e-kimlik sahiplerinin bu portalı X-road aracılığıyla kullanımına uygun hale getirmiştir. Dijital imza ile e-hizmetleri alabilme imkanına sahiptir, şimdiye kadar yaklaşık 234 milyon dijital imza atılmıştır (Kotka, Vargas ve Korjus, 2015, s. 4).

\section{Genişbant Stratejisi, Mobil Kimlik Hizmeti, E-Seçimler}

Geniş bant terimi, bir telekomünikasyon cihazının veya sinyalinin başka bir standart veya olağan bir sinyal ya da cihazdan daha geniş bant genişliğine (trafik için daha büyük kapasiteye) sahip olması anlamına gelmektedir (Attenborough, 1988, s.289). Vatandaşların e-hizmetlere erişimini kolaylaştırmak ve hızlı internet sağlayarak e-devletin gelişimini artırmak için 2005 yılında Geniş bant Stratejisini benimsemiştir. Ekonomik İşler ve İletişim Bakanlığı, Estonya'nın ana BİT şirketlerini kırsal alanlarda yeni nesil bir iletişim altyapısı kurmak için bir araya getiren Geniş Bant Geliştirme Vakfi'nı kurmuştur. Estonya Bilgi Toplumu Stratejisi (2007-2013), İnternet geniş bantının yaygınlaştırılmasından kaynaklanan e-hizmetlerdeki gelişmeleri kapsayacak şekilde değiştirilmiştir (Kalvet, 2012, s.143).

Dijitalleşme projesinin başarılı bir şekilde uygulanmasının en önemli sonuçlarından biri, 2005'teki yerel seçimleri için dijital kimlik doğrulama yoluyla çevrimiçi oylama imkanı olmuştur. Estonya, ülke çapında seçimlerini internet üzerinden düzenleyen dünyadaki ilk ülke olmuştur (Kabakuşak D., Kaya A., 2014; Demirel, D. 2010; Alvarez, Hall, ve Trechsel, 2009, s.497).

2007 yılında Mobil kimlik hizmeti başlatılmıştır. E-kimlik ile kullanılabilen hizmetlere mobil erişimi mümkün kılan bu uygulama aynı yıl yapılan parlamento seçimlerinde de vatandaşlar tarafından kullanılmıştır (Martens, 2010, s.213). 


\section{E-Yönetişim Akademisi (https://ega.ee/)}

Estonya e-dönüşümdeki başarısını metod olarak da yaymaya çalışmaktadır. Bu amaçla 2002 yılında E-yönetişim Akademisini kurmuştur (Nielsen, 2017, s.300). Akademi, bir yandan alanı geliştirmek için yaratıcı fikirler ve projelerin arayışı içindeyken, diğer yandan diğer ülkelere deneyimi ile ilgili danışmanlık yapmayı hedeflemektedir.

Akademinin çalışma alanları e-devlet, e-hizmetler, e-demokrasi ve siber güvenlik, yerel yöneticilerin eğitimi gibi konulardır.

Akademi, 60'ın üzerinde farklı ülkeden 3500'ün üzerinde yetkiliye eğitim vermiştir. Orta ve Doğu Avrupa, Asya ve Afrika'da e-Devletin geliştirilmesine yardımcı olmuştur. Avrupa Birliği ülkeleri (Finlandiya, İsveç ve Letonya) ile işbirliği de geliştirmiştir (de Carlos Sola, 2018, s.3).

\section{Tallinn Bilim Parkı}

2003 yılında Estonya Cumhuriyeti, Tallinn Teknoloji Üniversitesi ve Tallinn Şehir Yönetimi Tallinn Bilim Parkı geliştirme vakfını kurdu. Sitesinde tanım1 (https://www.tehnopol.ee/en/);

“Tallinn Bilim Parkı Vakfı, Estonya'da teknoloji temelli girişimciliği ilerletmeyi, bilim adamlarını ve girişimcileri bir araya getirmeyi ve çığır açan iş fikirlerinin gerçekleştirilmesi için uygun koşulları ve uygun ortamı sağlamayı amaçlayan bir bilim ve işletme kampüsüdür."

olarak geçmektedir.

Parkta bulunan 200'den fazla şirketin birçoğu, dünya çapındaki bilim parklarında başlatılan ekonomik büyümenin kaynakları haline gelmiştir. Amerika gibi gelişmiş ülkelerde inovasyon projeleri özel sektör taarafından dessteklenirken Tallinn'de devlet tarafından desteklenmektedir (Heller, 2017). Bu şirketlerin çoğu, Skype gibi alanında öncü ya da alan açıcı denebilecek (startup) şirketlerdir. Kompleks, startup girişimlere sermayesiz finansman desteği, seminer, eğitim, koçluk desteği vermenin yanısıra bir de startup inkübatör 'üne sahiptir. Bu inkübatörle, yeni girişim fikirlerine uzmanlık, koçluk ve aktivite desteği vermektedir. 


\section{Rusya'nın Siber Saldırısı ve Çözümler}

Estonya, Rusya'dan bağımsızlığını kazansa da Rusya'nın Estonya'ya saldırıları devam etmiştir. Bunlardan e-devletle ilgili olanı 2007'de gerçekleşmiştir. 2007'de Estonya Hükümeti, Rus İkinci Dünya Savaşı anıtını Estonyalılara göre Rus işgalini temsil ettiği için kaldırma kararı almış ancak bu karar, söz konusu anit1, Hitlere karşı Rus zaferini simgesi olarak kabul eden Estonya'daki Rus ya da Rus yanlısı halkın tepkisine yol açmıştır. Protestolarda pek çok insan yaralanmış ve sonucunda yaklaşık 1000 kişi tutuklanmıştır. Protestolar öfkeyi dindirmemiş şekil değiştirerek siber alana yönelmiştir, Estonya, tarihinde ilk siber saldırıya uğramıştır. Olayı Moldovalı bir grup Hacker üstlenmiş, Rusya hakkındaki şüpheler kanıtlanamamıştır. Saldırı, tüm hizmetlerini dijital ortamdan veren Estonya'nın e-devlet sistemini durdurmuş, sorunun çözülmesi günler sürmüştür (Ottis, 2008, s.1,2).

Estonya sorunun çözümü için NATO ve ABD ile işbirliğine gitmiştir. NATO, başkent Tallinn'e İşbirlikçi Siber Savunma Mükemmeliyet Merkezini açmıştır. Bu durum, Estonya'ya olası bir siber saldırının aynı zamanda NATO'ya saldırı olacağı anlamına gelmektedir. NATO'nun yanı sıra 2012 yılında Avrupa Birliği Bilgi Teknolojileri Ajansı da Tallinn'de bir merkez açmıştır (Antes, 2015, s.18).

Saldırıdan sonra güvenlik en önemli gündem maddesi haline gelmiş, 2009 yılında Estonya Bilişim Merkezi, hükümetin siber güvenlik yeteneklerini güçlendirmek amacıyla yeni bir savunma çerçevesi oluşturmuştur. Önlemleri kurumsallaştırmak için 2010 yılında polis ve gümrük muhafızları birimleri içinde Siber Suçlar Birimleri kurulmuş, bunun yanında Savunma Bakanlığı'na bağlı ve gönüllü̈lerden oluşan Siber Savunma Ligi kurulmuştur. Bu konu ile ilgili kurumlardan sonuncusu Estonya Bilgi Sistemi Kurumu'dur. Bu kurumun görevi kamu ve özel tüm şirketlerin siber korumasını garanti altına almaktır (Czosseck, Ottis, ve Talihärm, 2011, s.24).

2014 yılında Estonya hükümeti, siber saldırılar veya diğer acil durumlarda devlet hizmetlerinin işleyişini güvence altına almak amacıyla Sanal Veri Elçilikleri projesini başlattı. 'Sanal devleti' inşa etme vizyonunun bir parçası olan hükümet planı, ülkenin toprak bütünlügüune bakılmaksızın devletin dijital sürekliliğini güvence altına almayı amaçlamaktadır (Kotka ve Liiv, 2015, s.149). 
Proje ile birlikte sistem, diplomatik bir misyona sağlanan ayrıcalıklara sahip Lüksemburg'daki sunucularda yedeklenmektedir. Yani sistemin bulunduğu toprak Estonya toprağıdır ve Estonya merkezindeki olası bir istilası durumunda bile faaliyet göstermesine izin verecek şekilde tasarlanmıştır.

\section{E-dönüşümde Yeni İki Yönlendirici Kurum}

2014 yılında, tüm dijital yönetimi yönetmek için E-Estonya Konseyi oluşturuldu. Bu konseyi Başbakan ve diğer Bakanlar yönetir. Aynı zamanda Annika Uudelepp, Linnar Viik, David Hinrikikus ve tabii ki Taavi Kotka gibi programda çalışan teknik ve programcıları da içermektedir (de Carlos Sola, 2018, s.4).

Bir başka yeni platformda "Taslak Bilgi Sistemi Kurumu"dur (Kotka, Vargas ve Korjus, 2015, s. 3). Kurum, insanların yasama eylemlerini ve politika belgelerini incelemesini sağlayarak hükümet işlerinde açıklık ve şeffaflığ teşvik etmiştir.

\section{Estonyahlarn Dijital Kültürü}

Estonya dijital politikası ve hızlı teknolojik ilerleme, diğer faktörlerin yanı sira, Estonya toplumunun teknoloji dostu kültüründen, genel bir teknoloji bilinci ve onu kullanmaya hazır olmasında da kaynaklanmaktadır. Toplumun teknoloji dostu kültürünü Heller (2017, s.10) bir vatandaştan teknoloji ile ilgili duyduğu şu anektodla karakterize etmektedir:

"Bizim büyük abimiz yok, bizim küçük kardeşimiz var, gerekirse ona ne yapacağını söyleyebilir ya da dövebiliriz."

Estonya'nın dijital dönüşüm projesinin ana sorumlusu Taavi Kotka projenin başarısının altında yatan nedenin projenin halk tarafından benimsenmesi olduğunu belirtmiş ve projenin hedefi ile ilgili (Heller, 2017, s.10) "Toplumun inanması için yeterince büyük, yankı uyandıran bir hedef belirlemeliydik" demiştir. Bu yankıyı uyandırmak için projenin ana amacı ülkenin gelişmesi için bir devletten dijital bir topluma dönüştürme projesi olarak belirlenmiştir. Devletin bu stratejisi toplumda benimsenmiş, teknolojik iyimserlik ve ulusal gururun bir bileşimi olan bir 'e-vatanseverlik' duygusunu güçlendirmeyi de beraberinde getirmiştir (Tammpuu ve Masso, 2018, s.543). 
Gelinen noktada, Estonyalıların yaklaşık\% 95'i dosyalarını dijital olarak imzalamakta, vergi mükelleflerinin \% 96'sı vergilerini elektronik olarak beyan etmekte, banka işlemlerinin \% 99,6'sı çevrimiçi olarak yapılmaktadır, 2015 parlamento seçimlerinde seçmenlerin \%33'ü e-oy kullanmıştır (Aydın, 2021, s. 2).

Bugün Estonya, kamusal yaşamın neredeyse her günlük faaliyetinin bir e-hizmete, dolayısıyla ülkenin ortak etiketi olan "e-Estonya" dönüşümü için itici güç sağladığı bir teknik ve politik bir ekosisteme sahiptir. İnterneti insan hakkı olarak tanıyan, e-hizmete erişimi anayasal güvence altına alan, Mülk Tescil Etme, İnşaat İzinleri ile Mücadele, İş Kurma ve Sözleşmeleri Yürütme gibi işlemlerin kolaylığı konusunda Dünya Bankası verilerine göre ön sıralarda yer alan (2014 den bu yana ilk yirmide yer almaktadır) bir ülkedir. Estonya'nın dijitalleşmesi, ülkenin kalkınmasını da sağlamıştır. Devletin işi azaldı ve bu da kamu harcamalarını azaltmaya ve yolsuzluğu önlemeye yardımcı oldu. Öte yandan, İngiltere veya ABD'de yaşayan birçok Estonyalı göçmenin, oy kullanarak veya birçok kez orada işlerini yaparak ülkeleriyle hala temas kurmalarına yardımcı oldu.

Sonuç olarak, e-vatandaşlık projesinin bağlamı, yukarıda anlatılan ve zaten var olan altyapıdır. E-vatandaşlık bu altyapıyı kullanarak Estonya'nın kamu ve özel ağlarının verimliliğini artırmanın yanı sıra, hayati önemde, "konumdan bağımsız bir işletmeyi çevrimiçi olarak yönetmekle ilgilenen dünyadaki herkes için kullanılabilir bir ulusötesi dijital kimlik" sağlamayı amaçlamaktadır (Sullivan ve Burger 2017, s.470). “2025 yılına kadar 10 milyon e-Estonyalı" sloganıla duyurulan uygulama, yabancilara Estonya'nın yeniliği ve dönüştürücü potansiyelini, geniş X-Road altyapısını Estonya vatandaşı gibi kullanma imkânı sağlamayı teklif etmektedir.

\section{E-Vatandaşlık Konsepti}

Estonya, bölgesindeki diğer ülkeler gibi göç ve nüfusunun azalması ile ilgili problem yaşamaktadır. Bağımsızlığını kazandığından beri nüfusunun yaklaşık \%15'ini kaybetmiştir. Bunun temel nedeni, ülkenin eğitim seviyesinin yüksek olması ve gelişmiş ülkelerin beyin göçü için hazırladığı cazip imkanlardır (de Carlos Sola, 2018, s. 3). Bu sorunu çözmek için Estonya hükümeti dijital dünyanın fırsatlarından yararlanmayı strateji olarak belirlemiştir. 
Bürokrasiyi azaltmış, oylama, vergi ödemesi, işletme kaydı gibi işlemler ile bankacılık gibi hizmetlerin internetten kolayca alınmasını sağlamıştır.

E-vatandaşlık da yabancı sermayeyi cezbetmek için düşünülmüş ve eEstonya'nın bir marka değeri olarak pazarlanmasını içeren bir projedir. Evatandaşlık literatürde bir pazarlama stratejisi olan "ulus markalama"nın "kendiliğinden" ortaya çıkmış versiyonu olarak değerlendirilmektedir (Polese, Ambrosio ve Kerikmäe, 2020, s.22). Ulus Markalama yaklaşımına göre stratejik pazarlama yönetimi ile ülkeler, pazarlamanın konusu olabilir ve ülkenin kültürel ve politik özellikleri markalaştırılarak ekonomik gelişmenin bir unsuru haline getirilebilir genellikle hedef yabancı sermaye, uluslararası ortamda kabul görme, turizmde tanınmadır. (Özüdoğru ve Yüksel, 2019, s.331).

Ulus markalama tanımından da anlaşılabileceği gibi ulus kavramını pazarlanabilen bir meta olarak ele alırken devletin rolü de değişmektedir. Pazar mantığını devletin siyasi ve kültürel alanına aktararak, devletlerin artık bölge ve güç üzerinde değil, yatırım ve pazar payı üzerinde rekabet eden aktörler olduğu belirtilmektedir (Tammpuu \& Masso, 2018, s.544). Bu görüş aynı zamanda küresel kapitalizm ve neoliberal yönetişim koşulları altında devletin değişen rasyonalitesini karakterize eden 'rekabetçi devlet' kavramiyla da ilgilidir (Jansen, 2008, s.121). Bu koşullar altında, yerel sosyal dayanışma, vatanseverlik ve 'koruyucu devlet' için ortak olan ulusal refah gibi geleneksel hedefler, devletin küresel arenalarda rekabet edebilirliğini sürdürme ve geliştirme endişeleriyle yer değiştirir veya en azından iç içe geçmiştir (Kaneva, 2011, s.117). Yine de, bazı yazarların iddia ettiği gibi, ulusal markalama ulusun yeniden tanımlanması işlevini görebilir. Devletler, vatandaşlarına hitap edecek değerlerini yükselterek aynı zamanda küresel ortamda meşruiyetini artıracak bir dayanak olarak kullanabilir (Rusidze, 2019, s.77)

Ulus markalamanın pazarlama kampanyaları ile yönlendirilmesi öngörülürken Estonya'nın e-vatandaşlık projesi, Estonya'nın popülerliğini artırmış ve artan ilgi ile ulus markası haline gelmiştir.

2014 yılında E-vatandaşlık kavramı Estonya Parlamentosuna sunulduğunda oybirliğiyle kabul edildi, "10 milyon e-Estonyalı" fikri, Estonya Kalkınma Fonu'nun düzenlediği "En İyi Kalkınma Fikri 2015" yarışmasından hibe kazand. Kurulan e-Residency web sitesi ve abonelik listesi sosyal medya kanalları aracılığıyla viral oldu. Böylelikle proje, Estonya hükümeti 
onu tanıtmadan önce bile önemli bir uluslararası ilgi gördü (Sullivan, \& Burger, 2017, s.470). Uluslararası medyanın olumlu yansıması projenin Estonya toplumu içinde kabul görmesinde çok önemli bir faktördü.

E-vatandaşlık ulusal markalaması ile birlikte, Estonya'nın dijital bir devlet ve toplum, çekici bir iş ortamı, yaşamak veya ziyaret etmek için dostane bir ortam olarak tanınması bekleniyordu. Bu fikrin politika kavramsallaştırması, dijitalleşme, ekonomik büyüme ve rekabetçilik, ulusal itibar yönetimi ve markalamanın yanı sıra göç ve işgücü hareketliliği ile ilgili farklı politikaları da içermektedir.

Şekil 1'de e-vatandaşlığın çok boyutlu yapısı incelenmiştir.

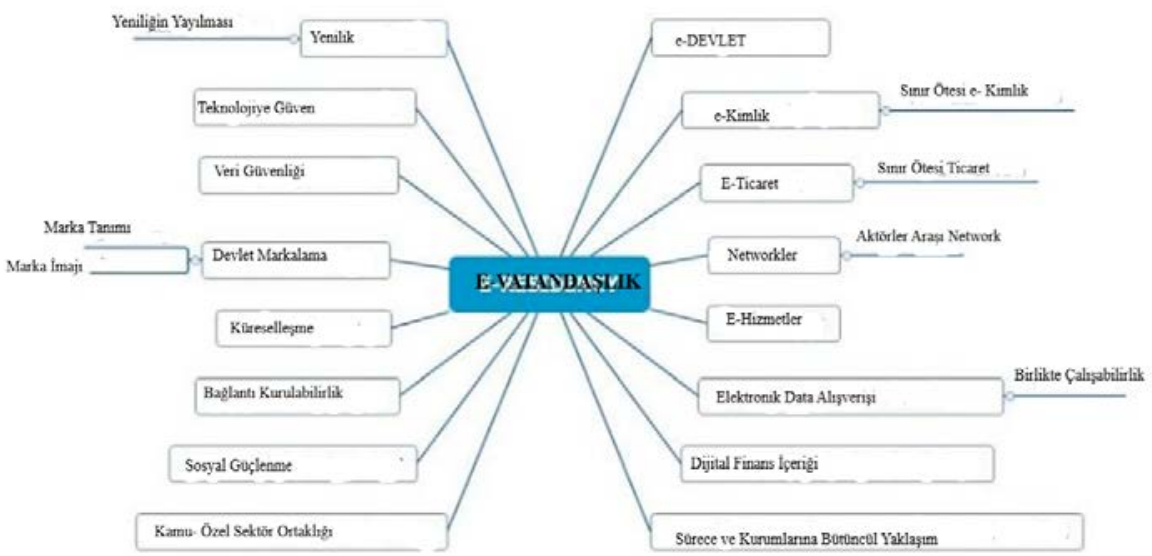

Şekil 1 E-Vatandaşlık inşasının çok boyutlu yapısı, (Korjus, del Castillo $\mathcal{E}$ Kotka, 2017, s.178'den uyarlanmıştır).

E-vatandaşlık heterojen ve birbirini dönüştüren bir ağ oluşturarak birden fazla unsurun (insanlar, teknolojiler, organizasyonlar, yönetim kararları, yetkinlikler, finansal kaynaklar, süreçler, hizmetler, teknoloji, dijital içerik, kanunlar, düzenlemeler, sosyo-kültürel normlar, tercihler vb.) sürekli müzakere ve etkileşimi olarak görülebilir.

Sistemin bileşenlerinin rolleri özetlenecek olursa (Kotka, Vargas ve Korjus, 2015, s. 5);

- Estonya 2020 için Dijital Gündemin Yaratıcıları: e- vatandaşlık girişimini ilk kez tartışan Kasım 2013 tarihli hükümet belgesi. 
- Fikrin Yaratıcıları: e-vatandaşlık fikrini ödüllü bir konsepte dönüştüren ve projeye stratejik destek sağlayan vizyoner liderler.

- Estonya Kalkınma Fonu: Başlangıçta "10 Milyon E-Estonya” konseptini tanıtan ve finanse eden yarışmayı düzenledi.

- Estonya Girişiminde yedi üyeli ekip: e- vatandaşlık projesinin yönetimini kolaylaştırır ve işbirliği yapan kamu, özel ve kar amacı gütmeyen sektör ortaklarıyla koordinasyon sağlar.

- E-Vatandaşlık Kurulu: Yedi üyeli ekip tarafından önerilen projenin stratejisini, hedeflerini ve bütçesini denetler.

- Kabine: Kurul tarafından önerilen projenin stratejisini, hedeflerini ve bütçesini denetler.

- e-Kimlik: E-Vatandaşlar için dijital dünyaya erişim anahtarı.

- X-Road: Estonya veri değişim katmanı, kamu ve özel sektör bilgi sistemleri arasında güvenli internet tabanlı veri alışverişini sağlar.

- Estonya Polisi ve Sınır Muhafızları: e-Vatandaşlık kartları için başvuru sürecini izler, başvuru sahipleri üzerinde geçmiş kontrolleri gerçekleştirir ve e-vatandaşlara e-kimliklerini verecek olan Estonya büyükelçiliklerine ve konsolosluklarına kartlar verir.

- Bilgi Sistemi Otoritesi (RIA): Ulusal bilgi sisteminin gelişimini ve yönetimini koordine eder ve korur.

- İçişleri Bakanlığı: e-Vatandaşlık uygulamaları ve süreçleri ile ilgili mevzuat geliştirir.

- Ekonomi ve İletişim Bakanlığı: Kamu sektörü BİT bütçesini yönetir ve uygulamalara nasıl yatırım yapılacağına ilişkin kararları formüle eder.

- Adalet Bakanlığı: İş ortamına ilişkin mevzuat geliştirir.

- Maliye Bakanlığı: e-Vatandaşın mali yönleriyle ilgili mevzuat geliştirir ve kanuna uygunluğunu gözden geçirir.

- Dişişleri Bakanlığı: Başvuru sahipleriyle yüz yüze görüşmeler yapar, parmak izlerini alır ve e-vatandaş başlangıç kitleri verir.

Estonya, yabancı sermayeyi cezbetme politikası için bir araç olarak yabancllara verdiği e-Kimlik ile dünyanın neresinde olursa olsun Estonya vatandaşı gibi e-hizmetler kullanma imkanı tanımakta, şirket kurmak ve yönetmek, anlaşma imzalamak, ödeme yapmak, bankacılık gibi işlemlerin hukukiliğini garanti altına almaktadır. E-vatandaşlık politikası yalnızca iş kurmayı değil yabancı uzmanların ikamet zorunluluğu olmadan Estonya için çalışabilmesini de kapsamaktadır. Başvuru sahibi, e-vatandaşlık başvu- 
rusu için Estonya'ya gitmeden, kapsamlı bir geçmiş kontrolünün ardından, New York'tan Tokyo'ya kadar otuz sekiz yabancı elçilikten herhangi birinden kartını alabilmektedir (Prause, 2016, s.216).

Programın başlamasından bu yana, e-ikamet sayısı 62.000'i aştı ve evatandaşlar, Estonya'da toplam 1.700 kişiyi istihdam eden 10.100'den fazla şirket kurdu. Programdan elde edilen doğrudan gelirin, programın yürürlükte olduğu yaklaşık beş yıl içinde 31 milyon Euro'ya ulaştığı tahmin edilmektedir (www.news.err.ee).

Özet olarak Estonya e-vatandaşlığı startup girişimi yaklaşımıyla ele almış, projenin başlangıcı, geliştirme yöntemleri ve organizasyonel uyarlamalarını bu yaklaşıma göre şekillendirmiştir.

E-vatandaşlığın uygulama sonuçları henüz tam olarak bilinmemektedir. Yine de şimdiye kadar ortaya çıkan pratik sonuçlar üzerinden projenin faydaları ve risklerinin bir değerlendirmesi yapılmaya çalışılmıştır.

\section{E-Vatandaşlık Konseptinin Güçlü Yanları ve E-Vatandaşlığın Avantajları}

Estonya, dünyadaki herkese ulus-ötesi dijital kimlik hakkı tanıyan ilk ülkedir. E-vatandaşlık, sitesinde vurgulandığı üzere dünyanın her yerinden sadece internet aracılığıyla kullanılabilmesi yönüyle bilişim teknolojilerinin mekan sınırını ortadan kaldırma potansiyeli ile ilgili vaatkar söylemini gerçekleştirmeye dair bir uygulama olarak karşımıza çıkmaktadır (https://eresident.gov.ee/). Her dünya vatandaşına girişimcilik imkanı tanıması vurgusuyla dijitalleşmeyle birlikte sınırların anlamını yitirmesi ile ilgili söylemleri desteklemektedir.

Dijital ve fiziksel alanlarını ayrı tutarak, sınırlarına ve kendi nüfusuna dokunmadan dünyadaki herkese dijital ortamını açarak dijital ortamda sınırlarını genişletmekte ve dijital ortamda yeni ilişkiler üretmektedir (Tammpuu, e Masso, 2018, s.245). Web sitesinde dünya vatandaşlarına hitap ederek dijital ortamda özel bir aidiyet türü geliştirmektedir.

Projenin yürütücü ekibinin e-vatandaşlık ağına dahil olan aktörlerin katkıları ve sonuçları üzerine yaptığı GZFT analizine göre e-vatandaşlığın güçlü yönleri ve fırsatları şu şekilde özetlenebilir (Korjus, del Castillo ve Kotka, 2017, s.178): 


\section{Güçlü Yönler}

- Yasal altyapısı oluşmuş, 15 yıllık e-devlet ve e-kimlik altyapısı üzerine inşa edilmiştir, minimum bürokrasi ve teknik değişikliklere hızlı tepki verebilen yüksek risk toleransina sahiptir.

- Kamu ve Özel Sektörden ulusal destek almaktadır ve Estonya kamuözel ortaklığında güçlü bir deneyime sahiptir. Özel sektör tarafından gelen e-vatandaşlarla çoklu iletişim kanalları kurulmuştur.

- Proje türünün ilk örneğidir ve ilk günlerden itibaren uluslararası Estonya işletmesi başvuru sayısı artmaktadır.

- Uluslararası basında artan ilgi nedeniyle markalaşmıştır, Uluslararası kuruluşlarla işbirliği sağlanmıştır.

\section{Firsatlar}

- Estonya ve yabancı hükümetler arasında daha güçlü işbirliği.

- Diğer platformlarla birlikte çalışabilirlik.

- E-Residency uygulama mağazası, tüm genel ve özel e-hizmetleri tek bir yerde içerebilir.

- "Brexit" gibi kararlar dijital işbirliği ihtiyacını güçlendiriyor.

- BM, DTÖ, Dünya Bankası gibi uluslararası kuruluşlarla daha güçlü işbirliği, e-İkamet uygulamalarını artırabilir.

- E-sakinler için hizmetlerin yükseltilmesi ve genişletilmesi (sağlık hizmetleri, akademik işler, vize başvurusu ve oturma izinleri, peer2peer ağları, vb.).

- e-Residency dijital kimlik platformunun farklı özel sektör platformlarıyla entegrasyonu, yeni hizmetlerin başlatılması

- Bir e-sakinin dijital kimlik kartını almak için daha uygun seçenekler.

- Sosyal güçlendirme: savunmasız veya boyun eğdirilmiş gruplara eşit dijital firsatlar.

- Uluslararası dijital ticaret işlemlerini yürütmek için otomatik ve daha kolay vergi yönetim sistemleri.

- SIM'siz cep telefonları bağlamında SIM'siz Mobil-Kimlik geliştirilmesi.

E-vatandaşlık konseptinde de anlatıldığı gibi E-vatandaşlık işlemleri basitleştirilmiş ve e-kimlik, başvuru sahibinin Estonya'yı fiziksel olarak ziyaretini gerektirmeden verilmektedir. Bu kimlik kartı ile e-vatandaş başka bir 
işleme gerek kalmadan Estonyalılar gibi e-devlet hizmetlerinden yararlanma imkanı tanımaktadır. Bu imkan Estonya'da geçici olarak bulunan kişiler tarafından kullanılabileceği gibi şirket kurmak isteyen ya da serbest meslek sahibi kişiler tarafından Estonya iş dünyasında bulunmak için de kullanılabilmektedir.

Estonya, mevzuat açısından Avrupa Birliği Rekabet Kurallarına bağlıdır ve orada çalışmak, ya da şirket sahibi olmanın hakları olduğu gibi yükümlükleri de AB ülkeleri aynıdır. Yani Estonya'da da vergi oranları diğer Avrupa Ülkeleri gibi \%20'dir (de Carlos Sola, 2018, s.8).

O halde bu bölümde, E-Estonya'da serbest meslek sahibi olmak ya da şirket sahibi olmak hangi durumlarda tercih edilmektedir ya da avantajl1dir? sorusuna cevap aramak gerekmektedir.

Sistem, özellikle gelişmekte olan dünyada $A B$ dışından girişimcileri ve serbest çalışanlara çeşitli fırsatlar sunmaktadır. Estonya e-ikametinin faydaları arasında, web sitesi sürekli olarak Estonya'nın Avrupa Birliği'ne (AB) üyeliği ve Avrupa'da ortaya çıkan Dijital Tek Pazar ile ilgili olarak evatandaşın sahip olabileceği avantajlara atıfta bulunmaktadır (Tammpuu, ve Masso, 2018, s.545). Bu nedenle, e-vatandaşlığın faydaları yalnızca Estonya'da sunulan belirli dijital hizmetlerle ilgili olarak değil, aynı zamanda daha geniş bölgesel fursatları da beraberinde getirmektedir. Estonya Evatandaşlığı ile kullanılabilen dijital imzaların ve kimlik doğrulamanın, Estonya hükümeti tarafından tanınması, aynı zamanda bugün itibarı ile Avrupa Birliği, Amerika, Moldova ve Panama (Heller, 2017) tarafından da tanınması demektir. Bu, bir Avrupa ülkesinin ekonomik istikrarını garanti eder ve diğer Avrupa ülkeleriyle ticaret yapma firsatı vermektedir.

Sistem azgelişmiş ülkelerin girişimcileri ve serbest çalışanları için ülkelerinde yaşarken, ülkelerinin olumsuz yasal zorunluluklarından bağımsız iş yapma firsatı sunmaktadır.

Azgelişmiş ülkelerdeki serbest meslek sahiplerinin ve girişimcilerin siyasi ve ekonomik istikrarsızlıklar, seyahat kısıtlamaları, bürokrasi gibi nedenlerle müşterilerine sağlamakta zorlanabilecekleri güven duygusunu (Paruse, 2016, s.216) , e-vatandaşlıkla Estonya, dolayısıyla AB garantisi ile verebilmeyi ve uzun vadeli rekabet avantajlarından yararlanmasını mümkün kılmaktadır. Bunun yanında azgelişmiş ülkelerdeki serbest meslek sahibi ve girişimcinin online satış, bankacılık, pazarlama gibi dijital imkanları sınırlı olabilmekte ve küresel ortamda müşteri bulmasını zorlaştırabilmektedir. E- 
vatandaşlık, serbest meslek sahibine Estonya'nın dijital altyapısını kullanarak müşteri artırma imkanı vermektedir (Roots ve Dumbrava, 2016, s.45). Evatandaşlık serbest meslek sahiplerinin iş potansiyellerinin önündeki engelleri kaldırarak verilen hizmet kalitesinin artması, küresel ortamda serbest meslek sahibi sayısının artması gibi olumlu gelişmelerle küresel rekabete de olumlu yönde katkıda bulunma avantajı sağlamaktadır.

E-vatandaşlığın temel motivasyonu, küresel rekabette, ekonomik krizlerin arttırdığ 1 belirsizlik ortamına bir alternatif olabilmesidir. Sistem, Estonya bankasında hesap açmayı ve siyasi istikrarsızlığı olan ülkelerdeki insanlar için çok yararlı olan uluslararası banka havaleleri yapmayı da mümkün kılmaktadır. Sistem aynı zamanda fiziksel olarak başka bir ülkede iş yapmanın, idari maliyetleri ve çifte vergilendirme, yerel ortak bulma gibi zorunluluklarından da bağımsız olma imkanı sunmaktadır (Uljala, ve Scupola, 2018, s.208). Bu yönüyle azgelişmiş ülkelerin yanında gelişmiş ülkelerdeki girişimcilere ve serbest meslek sahiplerine de avantajlar sunmaktadır.

E-vatandaşlığın serbest meslek sahibi ve girişimcilere sağladığ 1 önemli avantajlardan biri de özellikle startup niteliği taşıyan girişimlerin desteklenmesi için idari teknik mali her konuda destek vermeye çalışmasıdır. Altyapı kısmında da anlatıldığı gibi Estonya nitelikli işgücünü ve yenilikçi girişim fikirlerini çekebilmek için önemli bir know-howa sahiptir (de Carlos Sola, 2018, s.8) , bunun yanında teknopark ve üniversitelere ve onun potansiyelini hem dijital ortamda hem de fiziksel ortamda e-vatandaşa aktarabilecek işbirliğini içeren de bir networke sahiptir.

E-vatandaşlığın en çok tercih edildiği alanlar şirket yönetimi ve danışmanlık faaliyetleri ve yazılımdır. Başvuruların çoğunluğu Finlandiya, Rusya, Amerika Birleşik Devletleri, Ukrayna ve Birleşik Krallık'tandır (Kimmo, Pappel ve Draheim, 2018, s.420-425).

E-vatandaşlığı talep eden ülkelere bakıldığında ilk onda, Finlandiya (\% 15,11), Rusya (\% 7,53), Amerika Birleşik Devletleri (\% 5,83), Ukrayna (\% $5,79)$ Birleşik Krallık (\% 5,34), Almanya (\% 5,08), İtalya (\% 4,42), Letonya (\% $3,39)$, Hindistan (\% 3,22), Fransa (\% 3,05) olduğu görünmektedir.

Finlandiya, Letonya ve Rusya'daki yakın ülkelerden olduğu için ilgili yukarıda bahsedildiği gibi zaten Estonya'da iş yapan kişilerle açılanabilir. $\mathrm{AB}$ dışındaki talepler, $\mathrm{AB}$ çerçevesinde iş yapma motivasyonuna sahip olabilir. 
Amerika'dan gelen taleplerin yenilikçiliği merak ve devlete olan güvensizlikle açıklamak mümkündür.

Ingiltere' den gelen taleplerin ise Brexit oylamasından sonra arttı̆̆ belirsizliğe karşı girişimcilerin $\mathrm{AB}$ içinde kalmak için e-vatandaşlığı tercih ettiği belirtilmektedir.

E-vatandaşlık operatörleri tarafından yapılan bir araştırmaya göre, başvuru sahiplerinin yüzde 35'i projenin dünya vatandaşlı̆̆ı vurgusuna duyduğu sempati ya da bulunduğu ülkeden memnuniyetsizlik ve Estonya'nın özgürlükçü ve yenilikçi vatandaşlık konseptini daha çok beğenmesi nedeniyle tercih eden bireylerden oluşmaktadır (Kotka, Vargas \& Korjus, 2015, s. 9). Başvuru formlarında başvuru sahipleri, sınırları olmayan dijital bir ulus inşa etme fikrinden etkilendikleri için kaydolmaya istekli olduklarını belirtmektedir. Bu grubun ağırlığının artması belki de gelecek yıllarda evatandaşlık konseptinin ağır basan ekonomik vurgusunu azaltıp, sosyolojik vurgusunu artırma yönünde dönüştürücü bir beklenti oluşturabilir.

Tüm bu hizmetleri Estonya hangi amaçla vermektedir? sorusunun cevabı da E-vatandaşlı̆̆ın Estonya için avantajlarını açıklamaktadır.

E-vatandaşlığın ilk ortaya çıkma fikri Estonya'daki şirketlerin yabancı ortaklarının ülkede yaşadığı sorunlardır. Yabancı şirket ortaklarının bürokratik işlemleri Estonyalı ortaklarından daha uzun sürmesi sorununa çözüm bulmak başlayan e-hizmetlerde vatandaş olmayanların da yararlanmaları fikri ikinci dalga Estonya diasporasıyla daha yakın ilişki kurma fikri ile genişletilmiştir (Rusidze, 2019, s.77). Fikrin üçüncü dalgası, Estonya'nın ekonomik, politik ve kültürel kalkınmanın yaşandığı günümüzün küreselleşmiş dünyasında ekonomisini geliştirmek için yabancı uzmanlık ve yatırımı çekmeyi ve dünyanın her yerinden bu nitelikteki insanları sisteme dahil etmeyi hedefler.

1.3 milyon vatandaşı ile Estonya küçük bir ülkedir. 1,3 milyon vatandaşın yalnızca 650.000'i çalışma çağındadır ve yaşlanan nüfus ve göç nedeniyle bu sayının önümüzdeki on yılda azalması bekleniyor. Sistemin sorumlusu Raavi Kotka politikayı şöyle açıklıyor (Kimmo, Pappel \& Draheim, 2018, s.420): “Göçmenleri çekmek bizim için bir seçenek değil. İnsanlar İsveç veya Norveç'i tercih ediyor. Fiziksel olarak, nüfusumuzu iyileştiremiyoruz. Öyleyse bunu neden çevrimiçi yapmıyoruz?

Daha önce belirtildiği gibi Estonya, güçlü yönü olan e-hizmetlerini yabancı girişimcileri ülkeye çekmek için kullanmaktadır. Bu amaç için Estonya 
Dijital Gündeminde belirtildiği gibi İsviçre'nin bankaları için dünyada oluşmuş tanınırlık ve güvenin benzerini e-hizmetleriyle kendi ülkesi için yapmaya çalışmaktadır (Tammpuu ve Masso, 2018).

Ülkenin uygulamadan beklediği verimlilik, karlılık gibi kısa vadeli katkıların yanısıra, uzun vadede startuplara ve yazılım gibi sektörlerdeki serbest meslek sahipleri ile dijital bir network üzerinden sektörlerin gelişmesinde rol sahibi olmaktır.

E-vatandaşlık, bu avantajların yanında Estonya'daki şirketlere de şirket kurma ya da iş kurmanın gerektirdiği danışmanlık ya da ortaklıklar için eEstonya platformunda şirketlerin biraraya gelmesine imkan tanıyarak yeni bir iş alanı da açmaktadır (Prause, 2016, s.216).

Özetle, Estonya'nın e-İkamet erişimini genişletmeye çalışmasının ana nedeni, ülkenin ekonomisine katkıda bulunmaktır - e-yerleşiklere uygulanan doğrudan vergilendirme yoluyla değil, ürün ve hizmetler sunan Estonya şirketleri tarafından üretilen ekstra gelir (örn. banka hesapları, posta hizmetleri, hukuk ve vergi danışmanlığı) ile yapmaktadır. Bunun yanında sistemle uluslararası ortamda İsviçre gibi markası olan bir aktör olmayı hedeflemektedir.

\section{E-Vatandaşlığın Zayıf Yönleri Ve Riskleri}

E-vatandaşlık, Estonyalı olmayanlara Estonyalıların sahip olduğu bir şirket açma ve Estonya'nın şirketlerine verdiği hizmetlere erişimin yanı sıra bankacllık veya bir sözleşme imzalama izni gibi ticaret ve vergilendirme ile ilgili sahip olduğu bazı imkanları da verir. Ayrıca, güvenilir bir finansal hizmetler ağı, muhasebeciler, pazarlama uzmanları, ödeme sağlayıcıları ve diğer esakinler tarafından önerilen diğer iş hizmetleri ve girişimciler için birçok hükümetin hizmetlerine erişim gibi şirketin yönetimi için birçok başka hizmet sağlar (Roots, ve Dumbrava, 2016, s.45). Ancak sağladığı muazzam dijital erişilebilirliğe rağmen, vergi ikametgahı sağlamadığını ve Estonya'ya veya Avrupa Birliği'ne ücretsiz erişim sağlamadığını belirtmek önemlidir. E-vatandaşlık, pasaport olmadığı veya pasaport olarak kullanılamayacağ için Estonya vatandaşlı̆̆ını vermez (de Carlos Sola, 2018, s.8), dolayısıyla geçerli bir seyahat belgesi değildir. Program hala beta sürümünde olduğundan, bir e-vatandaşlık başvuru sahibinin karşılaşabileceği bazı zorluklar vardır. Bir şirkete kaydolmak için Estonya'da fiziksel bir adrese sahip olma 
şartını içerir. Ayrıca e-vatandaşlık otomatik olarak vergi muafiyeti anlamına gelmemektedir, bu nedenle çifte vergilendirme durumları meydana gelebilir (Kimmo, Pappel ve Draheim, 2018, s.420-427).

Tek tek dezavantajlarına geçmeden önce E-vatandaşlık konseptinin zayıf yönlerine değinmekte fayda vardır.

E-vatandaşlık, her ne kadar dijital dünyanın dönüştürücü yönüyle yeni bir aidiyet türü üretse de temel amaç Estonya'yı ekonomik yönden daha güçlendirmektir. E-vatandaşlık sitesinde de altı çizildiği gibi bağlantının dijital olduğuna vurgu yapılarak programın "yabancılar"a hitap ettiği belirtilmektedir (Aavik ve Krimmer, 2016, s.151). Bu yönüyle e-vatandaşlık ne Estonya ile ne de Estonyalılarla bağlılı̆̆ 1 ifade etmekte sadece dijital hizmetlere erişimi ifade etmektedir.

E-vatandaşlık sitesinde konsept, Estonya'daki dijital fırsatların başvuranlar tarafında ithal edilebileceğine dair bir söyleme sahiptir. Fiziksel herhangi bir hak vermeyen uygulama erişilebilen dijital alanlara ve çevrimiçi kalmaya vurgu yapmaktadır. Kullanılan dijital kavramlar ülkenin dijital olarak gelişmiş bir ülke olması yönünde marka imajı oluşturmaya yöneliktir (Polese, Ambrosio ve Kerikmäe, 2020, s.46).

Estonya, e-vatandaşlarla bağlantısını dijital ortamla sınırlı tutarak kendi çekirdek ulusunun fiziksel ortamda bütünlüğünü korumayı ön plana çıkarmaktadır. Bu yönüyle ekonomisini yabancılarla genişletme fakat kültürünü korumaya dair bu yaklaşım literatürde ulusun koruma refleksiyle yeniden kendini üretimi olarak görülmektedir (Tammpuu ve Masso, 2018, s.559). Bu refleks bir bakıma Estonya tarihi ile ilgilidir. 46 yıllık Rus işgalinden sonra, 1,3 milyonluk nüfusa sahip Estonya ülkesi (diğer birçok eski Sovyet cumhuriyeti gibi) modernizasyona ve bağımsızlı̆̆a entegre olamayan ve Rusça konuşan \%26’lık nüfusa sahiptir (de Carlos Sola, 2018, s.8). Halen Rusya'nın tehdidi altında olan ve saldırıya uğrayan ülkede kültür ve teknoloji önemli bir savunma mekanizması olarak düşünülmektedir . Nitekim e-kimlik altyapısında da anlatıldığı gibi Estonyalılar Rus işgali altındayken bağlılıklarını kaybetmemek için kendilerine ait nüfusun kaydını tutarak ve şu anda dijital imkanlarla diaspora ile bağlantı kurarak teknolojiyi kültürlerini korumak ve Rusya'ya karşı güçlenmek adına kullanmaktadirlar

Projenin yürütücü ekibinin e-vatandaşlık ağına dahil olan aktörlerin katkıları ve sonuçları üzerine yaptığı GZFT analizine göre e-vatandaşlığın 
zayıf yönleri ve riskleri şu şekilde özetlenebilir (Korjus, del Castillo ve Kotka, 2017, s.179):

\section{Zayıf Yönler}

- Projenin bütçesi sınırlıdır ve fonlar Estonya vatandaşları tarafından sağlandığı için projedeki kararların Estonya vatandaşlarının yararına olması gerekmekte, bu da uzun vadeli fırsatların kaçırılmasına neden olabilmektedir.

- Kamu ihaleleri ile ilgili düzenlemeler projenin satınalma süreçlerini yavaşlatmaktadır.

- Estonya vatandaşlarının sahip olduğu Mobil kimliğe e-vatandaşlar sahip değildir.

- Küresel erişim sinırlıdır.

- E-vatandaşlar tarafından banka hesabı açma işlemlerindeki zorluklar yaşanmaktadır.

- Estonyalı kamu görevlileri ile e-vatandaşlar arasındaki dil engeli mevcuttur.

- Bir adayın uygunluğuna ilişkin kriterler (Eğer, Estonya'nın ekonomisini kültürüne ya da bilimine, katkıda bulunmazsa reddelirmektedir.) belirsizdir.

- E-vatandaşların biyometrik verilerinin seyahat ve vize konusunda yabancılarla aynı statüde olmalarına rağmen 50 yıl boyunca saklanması zorunluluğu makul değildir.

- E-vatandaşlar, e-hizmetlere tek noktadan erişememektedir.

- E-vatandaşların vergilendirmesi konusunda mevzuattaa belirsizlikler bulunmaktadır.

\section{Tehditler}

- e-vatandaşlık ekibinin dağılması,

- Halkın projeye desteğinin azalması,

- Etik olmayan işlerin, kamu sektörünün mücadele kapasitesini aşması,

- Kullanıcıların ülkelerinde e-vatandaşlığın kullanılmamasına dönük politik ve yasal baskı,

- Yüksek teknoloji şirketlerine bağımlılık,

- Sistemin ileri teknolojiye adaptasyonunun olası zorlukları, 
- Siber saldırı riski,

- Sahte pasaportlara dayalı sahte dijital kimlikler,

- Mahkemelerin e-vatandaşlı̆̆ın karmaşık konseptini nasıl ele alabileceğine dair belirsizlik,

- Eski olayların dijital olarak imzalanmış e-kayıtlarının dijital kanıt olarak uzun vadeli korunmasına ilişkin belirsizlik.

E-vatandaşlığın finansmanını sağlayan Estonyalıların e-vatandaşlığı kabulü hem ekonomik alanda, hem de sosyo-kültürel alanda önemli bir risk alanıdır. Bu nedenle iki tarafın da beklentileri arasında denge kurmak gerekmektedir. Ancak sosyo-kültürel açıdan koruma refleksi geliştirmiş bir yaklaşımın uzun vadede bu dengeyi sağlaması zor görünmektedir.

Teknoloji ile ilgili riskler de altı çizilmesi gereken bir noktadır. E-kimliğin kötüye kullanılması, siber saldırılar ve gelişen teknolojiye projenin adapte edilmesi çok da öngörülüp önlem alınabilecek hususlar değildir. Şu an için yönetilebilir görünen sürecin e-vatandaş sayısı arttıkça kontrolden çıkması da çok aktörlü bir yapının networküne dayanan bu uygulama için düşünülmesi gereken konulardan biridir.

E-vatandaşlık sitesinde yabancıların Estonyalılarla aynı dijital imkanları kullanacağı vaad edilse de kimlik kartlarında farklılaştırmaya gitmiş ve hukuki işlemlerde e-vatandaşı izlenebilir kılmıştır. Bu uygulama, evatandaş açısından kimlik kullanımının izlenmesi ve istendiğinde kısıtlanması riski taşımaktadır (Tanel ve Sandra 2015, s. 75). Devletin bu uygulamasını sanal ve fiziksel vatandaşlar arasında e-oylama gibi uygulamalarda ayrım yapmasını kolaylaştırması açısından rasyonel olarak görmek mümkündür ancak vatandaşlıktan çıkarılma durumunda hak kaybına neden olma riski taşımaktadır.

Projenin hedef grubu, yatırımclar ve profesyonellerdir ve e-vatandaş seçilme (aynı zamanda vatandaşlıkta çıkarılma) kriteri Estonya'nın ekonomisine, kültürüne ve bilimine katkıda bulunmasıdır, ancak hedef kitlenin çoğunluğunun e-vatandaşlığı seçme sebebi ekonomik sebepler olabilir bu nedenle karşılıklı kültür ya da bilimsel alışverişe çok da yatkın bir proje olduğu söylenemez. Ayrıca bu katkı ile ilgili ölçülebilir bir kriter de mevcut değildir bu yüzden e-vatandaşın ne zaman, hangi kritere göre vatandaşlıktan çıkarılacağ

E-vatandaşlık bir hak değil, faydadır ve Estonya kendi yasalarında bu kullanım imkanını “Estonya devletinin e-hizmetlerinin kullanımında meşru 
menfaati" şartına bağlamaktadır. Mevzuatta, bu menfaatin ne yapılınca sağlanacağı ile ilgili somut ilkeler yoktur. Bu belirsizlik e-vatandaş ile Estonya devleti arasındaki ilişkiyi e-vatandaş aleyhine bozmaktadır (Särav ve Kerikmäe, 2016, s.65). Bunun yanı sıra başvuru sahibinin bu muğlak kritere uygunluğunun değerlendirilmesinde ve vatandaşlıktan çıarılmasında hatta daha sonrasında Estonya bir e-vatandaşın güvenilirliğini tüm erişilebilir kaynaklardan kontrol etme yetkisine sahiptir, onunla ilgili bilgileri veri tabanlarında 50 yıl tutma yetkisine sahiptir ve bunun için ilgili kurumları dahil edebilir ve kimlik ve işlem verilerinin doğrulanması için önceden bildirimde bulunmaksızın gerekli veri toplamalarını sorgulayabilir (Kassen, 2019, s.552) . Vatandaşlık açısından bakıldığında aslında statüsü bir yabancıdan farksız olan e-vatandaşın bu denli belirsizlikle karşı karşıya bırakılması ve hukuki ve teknik takibe alınması, kullanacağı imkanlarla orantısızdır.

Estonya, e-kimlik uygulamasını genişletmeye başlarken temel amacı dünyanın herhangi bir yerinden erişim olmadığı için her genişleme dalgasinda yasal çerçevesine ve teknolojik korumaya dönük önlemlere eklediği yeni düzenlemeler, bugün birbiriyle harmoni içinde değildir. Özellikle teknolojik güvenlik ile ilgili koyduğu korumacı tedbirler temel hak ve özgürlükleri ihlal edecek niteliklere ulaşmıştır (Särav ve Kerikmäe, 2016, s.65).

Yukarıdaki risk ve olumsuzlukların yanında, başvuru süreci kolay olsa da, iş yapma ve diğer faaliyetlerin önündeki engeller devam etmektedir. Örneğin, bir banka hesabı açmak veya bir şirketteki hisseleri satmak için, evatandaşların banka yetkilileri veya noterlerle görüşmek üzere Estonya'ya gitmesi gerekir ve bunun için vize alması gerekmektedir (Kotka, Vargas ve Korjus, 2015, s. 8).

Benzer bir şekilde, Estonya'da bir şirket kurulduğunda, şirket sahibinin vergi numarası alması gerekir, başvuru online olduğu halde Estonya Vergi ve Gümrük Kurulu gerekli gördüğü takdirde başvuru sahibine ek sorular sorma yetkisine sahiptir ve bu işlem için fiziksel olarak Estonya'da olmak gerekmektedir. Ek olarak, program, özellikle e-vatandaşlar için tasarlanmadığından e-hizmetlerin kullanımında dil bariyeri vardır. Bu konuda yapılan bir araştırmada hizmetlerin çoğunun İngilizceye çevrilmediği, çevrilenlerin çoğunda da çeviri hataları olduğu tespit edilmiştir (Kimmo, Pappel, ve Draheim, 2018, 418). 


\section{Sonuç}

Estonya, vatandaşlar için olduğu kadar işletmeler için de e-devlet uygulamaları ve hizmetleri oluşturmadaki başarısıyla ön plana çıkmıştır. Estonya, elektronik kimliğin benzersiz genişlikte kullanımı ve dijital yönetim, eoylama gibi hizmetlerde dünyada rekabet avantajına sahiptir. Bağımsızlığının ilanından itibaren kalkınmayı ve yeni toplumun inşasını teknolojik altyapı ile birlikte tasarlayan devlet, yüksek güvenlikli e-kimlik uygulaması, geniş internet erişimi politikası, X-Road sayesinde kurduğu adem-i merkezi teknik altyapısı ve teknoloji dostu bir kültüre sahip olan toplumu ile dijital bir devlet ve toplum kurmakta zorlanmamıştır. Estonya e-Devletinin başarı öyküsü, e-Estonya'nın başarılı bir ülke markası olarak ön plana çıkmasına ve uluslararası ortamda dikkat çekmesine neden olmuştur. Kurduğu EYönetişim Akademisi ile E-devlet deneyimini metot olarak diğer ülkelere yaymaya başlayan ülke, kimlik sisteminin de ulusal bir marka haline gelebileceğini keşfetmiştir.

İlk başta Estonya'da bulunan yabanciların neredeyse tamamen dijitalleşmiş kamu hizmetlerini almasındaki mağduriyetlerini giderme amacıyla başlatılan uygulama, sonrasında Estonya diyasporası ve Estonya' da yatırım yapmak isteyen ya da çalışmak isteyen kişileri de içerecek şekilde genişletilmiştir. Uygulama, güçlü bir altyapı ve pratikteki ihtiyaçlardan doğmuş ancak dünyada benzersiz olduğu için uluslararası arenada çok fazla ilgi görmüş̧ür.

Görülen bu ilgiden de hareketle şekillendirilen proje, Estonya'nın işgücü kaybına bir çözüm ve ekonomisini güçlendirmek için bir fırsat olarak değerlendirilmiş ve bu amaçlar üzerine inşa edilmiştir. Ulus markalama ile dünyaya sunulan bu proje, Dijital dünyada, devlet ile kendi vatandaşı olmayan herhangi birini ilişkilendirmektedir. Uygulama her ne kadar ekonomik amaçlarla inşa edilse de ürettiği yeni aidiyet ilişkisi, dijital ortamların sınırları ortadan kaldırma söylemi açısından pratikteki ilk uygulamasıdır denilebilir.

E-vatandaşlık konsepti diğer ulus markalamaların aksine bir kampanyayla başlamamış görülen ilgiye göre kendiliğinden gelişmiştir. Konsept, dünya vatandaşlığına, sınırların engel olmadığına ve Estonya'nın isteyen herkese açık olduğuna dair vurgular yapsa da uygulama ile farklılık göstermektedir. Her şeyden önce e-vatandaşlık sadece dijital ortamda tanınan 
imkanlara yöneliktir. Herhangi bir hak ilişkisi yerine imkanlardan faydalandırtmayı içermektedir ve bu imkanlar sadece dijital ortamla sınırlıdır. Evatandaşlık uygulaması, dijital ortam ile fiziksel ortamı keskin bir şekilde ayıran hukuki ve teknik düzenlemeler ve önlemlerle çerçevelenmiştir. Ekimlik, kullanıcısına fiziksel kimliğin faydalarını sağlamamaktadır. Sağlanan imkanlar iş fırsatları ile ilgilidir ve Estonya'nın ekonomik, kültürel ve bilimsel gelişmesine katkıda bulunmak gibi muğlak bir şarta bağlıdır ve Estonya bu şartı sağlamayan e-vatandaşların statüsüne son verebilmektedir. Estonya, olası bir yatırım ve çalışma ilişkisi durumunda e-vatandaşı, eimzasından takip edebilme ve işlemlerini sınırlayabilme, vatandaşlıktan çıkardığı kişileri güvenlik gerekçesiyle açık tüm kaynaklardan ve o kaynakların otoritelerinden takip edebilme, bu kişilerin verilerini 50 yıl sistemlerinde tutabilme yetkisine sahiptir. Estonya, e-kimlik uygulamasını genişletmeye başlarken temel amacı dünyanın herhangi bir yerinden erişim olmadığı için her genişleme dalgasında mevzuatına ve teknolojik korumaya dönük önlemlere eklediği yeni düzenlemeler bugün birbiriyle harmoni içinde değildir. Özellikle teknolojik güvenlik ile ilgili koyduğu korumacı tedbirler temel hak ve özgürlükleri ihlal edecek niteliklere ulaşmıştır.

E-vatandaşlık konseptinin altında yatan dijital toplum ve dünyaya açık Estonya söylemlerinin uygulamada Estonya'yı ekonomik açıdan güçlendirmek ve ulusal alanı korumak için ticari bir marka olarak sunulduğu söylenebilir. Dijital ortam küresel ile yerel olan arasındaki mesafeyi kaldırsa da bu uygulamadan hareketle Estonya'nın e-vatandaşlar ile kendi vatandaşları arasındaki mesafeyi korumasına (Tammpuu ve Masso, 2018, s.559) da yardımcı olduğu görülmektedir.

Ulus markalama perspektifinden eleştirilen e-vatandaşlık konsepti, uygulamada getirdiği yenilikler ve fikir olarak sanal dünyada farklı devletvatandaş ilişkileri üretmede ilham vericidir. Öncelikle uzun bir işgal sürecinden sonra 1990'larda başlayan devlet deneyimini kısa bir sürede hem dijital topluma dönüştürmesi hem de e-devlette bir marka haline gelmesi önemli bir başarıdır, kurduğu e-devlet sistemi hem güvenlik hem de etkinlik açısından güçlüdür ve diğer ülkeler tarafından ithal edilen bir yönteme sahiptir. 1.3 milyon nüfusu ile tüm dünyaya kendi e-devlet sistemini kullandırmayı ve yeni bir aidiyet türü geliştirecek kadar dijitalize bir sisteme sahiptir. E-vatandaşlık uygulaması, hukuki ve teknik sıkıntıları olsa da en azından hedef kitlesi için önemli fırsatlar sunmaktadır. Hedef kitlesine, e- 
devlet hizmetlerinin yanında kendi yenilikçi yaklaşımının bir ürünü olan know-how desteği ve uzmanlık desteği sunmaktadır. Özellikle azgelişmiş ülkelerde hukuki, ekonomik ve teknik engellerden dolayı iş kurmakta zorluk çeken girişimciler, startup girişimcileri ve serbest meslek çalışanlarına kendi yalın bürokrasisi, yenilikçi ve destekçi anlayışıyla katkıda bulunmaktadır. Azgelişmiş ülkelerdeki girişimciler ve serbest meslek sahiplerinin yanı sıra belirsizliği artan küresel rekabet ortamında gelişmiş ülkelerin girişimcileri ve serbest meslek sahiplerine de $A B$ networkünü kullanma imkanı tanımaktadır ve bu yönleriyle uluslararası ortamda ilgi görmektedir.

Uygulamanın başarısını artırmak için öncelikle sunulan konsept ile uygulama arasındaki farkın giderilmesi gerekmektedir. Birbiriyle uyumsuz hukuki ve teknik çerçevenin yeniden düzenlenmesi gerekmektedir. Estonya, her ne kadar uzun süren işgalden dolayı korumacı bir politika izlemek zorunda hissetse de dijital ve fiziksel ulus ayrımını yumuşatması yatırım yapmasını beklediği startupların ya da yabancı sermayenin oranını artırmasını sağlayacaktır. Uygulamanın diğer ülkelerce de benimsenmesi yine başarıyı artıracak bir faktördür.

Sonuç olarak Estonya, ulus ötesi bir dijital kimlik ve vatandaşlık sunan ilk ülkedir. Bu uygulamanın sonuçlarını öngörmek zordur, çünkü daha önce böyle bir deneyim yaşanmamıştır. E-vatandaşlar dijital kimlik edindiklerinde e-Estonya mecrasında tüzel kişilik elde etmektedir. Bu hem kullanıcllar, hem de diğer ülkeler tarafından daha önce tecrübe edilmediği için güven uygulamaya karşı güven zamanla oluşacaktır. Ancak e-devletin sınır ötesi kullanımının diğer devletler tarafından ilgi görmesi ve yaygınlaşması potansiyeli vardir.

E-vatandaş sayısının artması ile beklentileri de artacak ve bu Estonya'nın uygulamayı revize etmesinde göz önünde bulundurması gereken unsurlardan biri olacaktır. Bu sayede üretilen yeni aidiyet ilişkisi de evrilme ve gelişme imkanı bulabilecektir. Geliştirilen aidiyet ilişkisinin güçlenmesi durumunda ulus-devlet ve vatandaşlık kavramlarının da yeniden üretilebileceği düşünülebilir. 


\title{
EXTENDED ABSTRACT
}

\section{The New Citizenship Concept in The Digital World: Case of E-Citizenship in Estonia}

\author{
Hatice Koç \\ Atatürk Culture, Language and History Supreme Council
}

E-Estonia is one of the most ambitious e-government applications in digital state administration today, as it covers all elements of the state and changes the daily lives of citizens. Estonia gathered on a single platform and made available to the public all government services like legislative, voting, education, justice, healthcare, banking, taxes, policing. Estonia has come to the fore with its success in creating e-government applications and services for businesses as well as citizens. Estonia has a competitive advantage in the world in uniquely wide use of electronic identity and services such as digital management and e-voting.

Since its declaration of independence, the state, which has designed the development and the construction of the new society with technological infrastructure, has not had difficulty in establishing a digital state and society thanks to its decentralized technical infrastructure and a technologyfriendly culture. The success story of the Estonian e-Government has led eEstonia to stand out as a successful country brand and attract attention in the international environment. The country has established the EGovernance Academy, and with this it has begun to spread the Egovernment experience to other countries as a method, and discovered that the identity system can also become a national brand.

The practice, which was initially started with the aim of eliminating the grievances of foreigners in Estonia in receiving almost completely digitalized public services, was later expanded to include diaspora and people who want to invest or work in Estonia. The application has emerged out of a strong infrastructure and practical needs, but it has received a lot of attention in the international arena as it is unique in the world.

The project, shaped by this interest, has been evaluated as a solution to the loss of labor force in Estonia and an opportunity to strengthen its economy and was built on these objectives. This project, introduced to the 
world with nation branding, associates the state with anyone who is not its citizen in the digital world. Although the application is built for economic purposes, it can be said that the new identification relationship it produces is the first application in practice in terms of the discourse of eliminating borders in digital environments.

Unlike other nation branding, the concept of e-citizenship has not started with a campaign, but has developed spontaneously according to the interest it attracted. Although the concept emphasizes world citizenship, an unlimited world and the openness of Estonia to anyone who wishes, it differs in practice. First of all, e-citizenship is only for the opportunities offered in the digital environment. It involves making use of opportunities instead of any rights relationship and these opportunities are only limited to digital world. The practice of e-citizenship is framed by legal and technical regulations and measures that sharply separate the digital and physical environment. Eidentity does not provide the benefits of physical identity to its user. The offered opportunities are related to business opportunities and are subject to the vague condition of contributing to the economic, cultural and scientific development of Estonia, and Estonia can end the status of e-citizens who do not meet this requirement. In the case of a possible investment and working relationship, Estonia has the authority to follow the e-citizen from their esignature and limit their transactions, to follow the persons who have been expelled from their citizenship from all open sources and the authorities of those sources for security reasons, and to keep their data in their systems for the following 50 years. As Estonia was starting to expand e-citizen application, its main purpose was not to be accessed from any place in the World. Thus, new regulations added to legislation and measures for technological protection in every expansion wave subjected towards e-citizen users are not in harmony with each other today. In particular, the protective measures it has taken regarding technological security have reached the phases that violate fundamental rights and freedoms.

It can be argued that the digital society underlying the concept of ecitizenship and the Estonian discourses open to the world are presented in practice as a trademark to strengthen Estonia economically and to protect the national space. Although the digital environment removes the distance between the global and the local, it is seen that it also helps Estonia to maintain the distance between e-citizens and its own citizens. 
The concept of e-citizenship, which is criticized from the perspective of nation branding, is inspiring to produce different state-citizen relations in the virtual world as the innovations and ideas it brings in practice. First of all, transforming the state experience that started in the 1990s after a long occupation process into a digital society and becoming a brand in the egovernment in a short time is an important success, the e-government system is strong in terms of both security and efficiency and it has own method imported by other countries. With a population of 1.3 million, it has a system that is digitalized enough to enable the whole world to use its own egovernment system and develop a new type of belonging. Although the ecitizenship application has legal and technical difficulties, it offers important opportunities at least for the target audience. In addition to e-government services, it provides know-how support and expertise support, which is a product of its own innovative approach, to its target audience. Estonia contributed especially in underdeveloped countries to entrepreneurs who have difficulty in establishing business due to legal, economic and technical barriers, startup entrepreneurs and freelance professionals with their own lean bureaucracy, innovative and supportive understanding. In addition to entrepreneurs and self-employed persons in underdeveloped countries, it also enables entrepreneurs and self-employed persons of developed countries to use the EU network in an increasingly uncertain global competition environment and attracts attention in the international environment with these aspects.

In order to increase the success of the application, the difference between the concept presented and the application must be eliminated. Legal and technical framework that is incompatible with each other needs to be rearranged. Although Estonia felt obliged to pursue a protectionist policy due to the prolonged occupation, softening the digital and physical national divide will increase the proportion of startups or foreign capital Estonia expects to invest. The adoption of the practice by other countries is also a factor that will increase success.

As a result, Estonia is the first country to offer a transnational digital identity and citizenship. It is difficult to predict the consequences of this practice because such experience has never been experienced before. When e-citizens acquire a digital identity, they acquire legal personality in the eEstonia channel. Since this has not been experienced before by both users 
and other countries, confidence in the application will build over time. However, the cross-border use of e-government has the potential to be attracted and widespread by other states.

With the increase in the number of e-citizens, their expectations will also increase and this will be one of the factors that Estonia should consider in revising the application. In this way, the new belonging relationship created will also have the opportunity to evolve and develop. It can be thought that the concepts of nation-state and citizenship can also be reproduced if the newly developed relationship of belonging becomes stronger.

\section{Kaynakça / References}

Aavik, G., ve Krimmer, R. (2016). Integrating digital migrants: Solutions for crossborder identification from e-residency to eidas. a case study from Estonia. International Conference on Electronic Government içinde(s. 151-163). Springer, Cham.

Alvarez, R. M., Hall, T. E., ve Trechsel, A. H. (2009). Internet voting in comparative perspective: the case of Estonia. PS: Political Science and Politics, 497-505.

Anthes, G. (2015). Estonia: a model for e-government. Communications of the ACM, 58(6), 18-20.

Attenborough, K. (1988). Review of ground effects on outdoor sound propagation from continuous broadband sources. Applied acoustics, 24(4), 289-319.

Aydın, Y. A. (2021). Quick comparison of e-government systems of Estonia and Turkey. 20. 01.2021 tarihinde www.academia.edu.tr adresinden erişilmiştir.

Björklund, F. (2016). E-government and moral citizenship: the case of Estonia. Citizenship studies, 20(6-7), 914-931.

Czosseck, C., Ottis, R., ve Talihärm, A. M. (2011). Estonia after the 2007 cyber attacks: Legal, strategic and organisational changes in cyber security. International Journal of Cyber Warfare and Terrorism (IJCWT), 1(1), 24-34.

de Carlos Sola, J. (2018). Process of modernization and technological development in Estonia. 20.01.2021 tarihinde https://pdfs.semanticscholar.org/7fca/85a70be8f11b322226130a2b7b07a68283 12.pdf adresinden erişilmiştir.

Demirel, D. (2010). yönetişimde yeni bir boyut: E-yönetişim. Türk İdare Dergisi, 466, 6594.

Hartleb, F. (2020). E-Estonia: “Europe's Silicon Valley” or a New “1984”?. Redesigning Organizations içinde (s. 215-228). Springer, Cham. 
Jansen, S. C. (2008). Designer nations: Neo-liberal nation branding-Brand Estonia. Social identities, 14(1), 121-142

Kabakuşak D. ve Kaya A., (2014). Estonya'da uygulanan e-devlet uygulamalarının Türkiye'de e-devlet uygulamarıyla mukayesesine dair bir çalı̧şma. AfroAvrasya Kaтu Yönetimi Uygulamalar ve Sorunlarn, TODAIE, 853-863

Kalja, A., Robal, T., ve Vallner, U. (2015). New generations of Estonian eGovernment components. In 2015 Portland International Conference on Management of Engineering and Technology (PICMET) içinde (s. 625-631). IEEE.

Kalvet, T. (2012). Innovation: a factor explaining e-government success in Estonia. Electronic Government, an International Journal, 9(2), 142-157.

Kaneva, N. (2011). Nation branding: Toward an agenda for critical research. International journal of communication, 25(5), 117-141

Kassen, M. (2019). Open data and e-government-related or competing ecosystems: a paradox of open government and promise of civic engagement in Estonia. Information Technology for Development, 25(3), 552-578.

Kerikmäe, T., ve Nyman-Metcalf, K. (2012). Less is more or more is more? Revisiting universality of human rights. International and Comparative Law Review, 12(1), 39-56.

Kimmo, M., Pappel, I., ve Draheim, D. (2018). E-residency as a nation branding case. Proceedings of the 11th International Conference on Theory and Practice of Electronic Governance içinde (s. 419-428).

Kimmo, M., Pappel, I., ve Draheim, D. (2018). E-Residency as a nation branding case. In Proceedings of the 11th International Conference on Theory and Practice of Electronic Governance içinde (s. 419-428), IEEE.

Korjus, K., del Castillo, C. I. V. A., ve Kotka, T. (2017). Perspectives for e-Residency strenghts, opportunities, weaknesses and threats. 2017 Fourth International Conference on eDemocracy \& eGovernment (ICEDEG) içinde (s. 177-181). IEEE.

Kotka, T., ve Liiv, I. (2015). Concept of Estonian Government cloud and data embassies. In International Conference on Electronic Government and the Information Systems Perspective içinde (s. 149-162). Springer, Cham.

Kotka, T., Vargas, C., ve Korjus, K. (2015). Estonian e-Residency: Redefining the nation-state in the digital era. University of Oxford Cyber Studies Programme working paper, 3.

Lember, V., Rainer K. ve Tõnurist, P (2018). "Technological capacity in the public sector: the case of Estonia." International Review of Administrative Sciences, 84(2), $214-230$. 
Martens, T. (2010). Electronic identity management in Estonia between market and state governance. Identity in the Information Society, 3(1), 213-233.

Mets, T. (2017). From the educational tiger leap program to the ICT startup booming in Estonia. In 2017 15th International Conference on Emerging eLearning Technologies and Applications (ICETA) içinde (s. 1-4). IEEE.

Nielsen, M. M. (2017, June). eGovernance and online service delivery in Estonia. In Proceedings of the 18th Annual International Conference on Digital Government Research, 300-309.

Ottis, R. (2008). Analysis of the 2007 cyber attacks against estonia from the information warfare perspective. Proceedings of the 7th European Conference on Information Warfare.

Özüdoğru, Ş., ve Yüksel, A. H. (2019). Ulus markalama ve beslendiği kaynaklar: Bir derleme. Bitlis Eren Üniversitesi Sosyal Bilimler Enstitüsü Dergisi, 8(1), 329-349.

Parsovs, A. (2020). Estonian electronic identity card: security flaws in key management. 29th \{USENIX\} Security Symposium (\{USENIX\} Security 20), içinde (s.1785-1802).

Polese, A., Ambrosio, T., ve Kerikmäe, T. (2020). Estonian identity construction between nation branding and building. Czech Journal of International Relations, 55(2), 22-46.

Prause, G. (2016). E-Residency: A business platform for Industry 4.0?. Entrepreneurship and Sustainability Issues, 3(3), 216-227.

Priisalu, J., ve Ottis, R. (2017). Personal control of privacy and data: Estonian experience. Health and technology, 7(4), 441-451.

Republic of Estonia. (t.y). The Website of E-Government. 18.01.2021 tarihinde https://ega.ee/ adresinden erişilmiştir.

Republic of Estonia. (t.y). The Implementation of E-Residency, 18.01.2021 tarihinde https://e-resident.gov.ee/ adresinden erişilmiştir.

Republic of Estonia (t.y). The News from The Website of E-Government, 18.01.2021 tarihinde https://www.news.err.ee adresinden erişilmiştir.

Roots, L., ve Dumbrava, C. (2016). E-citizenship opportunities in the changing technological environment. In The Future of Law and eTechnologies (pp. 45-56). Springer, Cham.

Rusidze, N. (2019). Estonia, regional challenges and state brand. Köz-gazdaság-Review of Economic Theory and Policy, 14(1), 77-86.

Särav, S., ve Kerikmäe, T. (2016). E-residency: A cyberdream embodied in a digital identity card?. In The Future of Law and eTechnologies içinde (s. 57-79). Springer, Cham. 
Sullivan, C., ve Burger, E. (2017). E-residency and blockchain. Computer Law E Security Review, 33(4), 470-481.

Tammpuu, P., ve Masso, A. (2018). 'Welcome to the virtual state': Estonian e-residency and the digitalised state as a commodity. European Journal of Cultural Studies, 21(5), 543-560

Tanel, K., ve Sandra, S. (2015). Legal impediments in the EU to new technologies in the example of e-residency. Baltic Journal of Law $\mathcal{E}$ Politics, 8(2), 71-90.

Tehnopol. (t.y). The Website of Tehnopol. 18.01.2021 tarihinde https://www.tehnopol.ee/en/, adresinden erişilmiştir.

Uljala, L., ve Scupola, A. (2018). Motivators and inhibitors of e-Residency adoption for global e-entrepreneurship. Services, Experiences and Innovation: Integrating and Extending Research içinde (s. 208-223). Edward Elgar Publishing.

\section{Kaynakça Bilgisi / Citation Information}

Koç, H. (2021). Dijital dünyada yeni vatandaşlık konsepti: Estonya'da Evatandaşlık örneği. OPUS-Uluslararası Toplum Araştırmaları Dergisi, 17(35), 2254-2289. DOI: 10.26466/opus.869773 